\title{
Rainfall Triggered Slope Instability Analysis with Changing Climate
}

\author{
Prity Dhanai $^{1} \cdot$ V. P. Singh ${ }^{1} \cdot$ Pramod Soni $^{1}$
}

Received: 22 June 2021 / Accepted: 10 November 2021/Published online: 21 January 2022

(C) Indian Geotechnical Society 2021

\begin{abstract}
Slope instability triggered by rainfall is common in tropical countries like India, where the soil of hill slopes are generally in unsaturated condition, having higher strength than in the saturated condition due to matric suction. This study aims to investigate the change in pore water pressure (PWP) with rainfall infiltration into the slope and the corresponding effect of the slope stability on different hill slopes from different regions of India. By applying rainfall on the surface of slope as a flux boundary condition, a transient seepage analysis is performed using SEEP/W, and the corresponding results in the form of PWP distribution within the slope are used as input for SLOPE/ W program of Geostudio 2018 R2, to check the stability of slope. This study involves the use of CMIP5 (Coupled model intercomparision project phase 5) simulations for rainfall data of different regions for the duration of 2015-2050, 2051-2075 and 2076-2100; which is completely based on non-stationary approach (i.e., the statistics of extremes changes with time) rather than the conventional methods of extracting rainfall data that are based on stationary approach. The stability of different slopes is checked for 95 percentile rainfall intensity as well as for maximum rainfall intensity for a period of 2015-2100, and the analysis is performed for 5 days for which the duration of rainfall is considered to be $24 \mathrm{~h}$. It is concluded that due to climate change, slopes which may be marginally stable under historical and present rainfall events can fail under projected precipitation estimates, and this can be understood by the results of Haflong slope stability analysis
\end{abstract}

Prity Dhanai

pdpritydhanai20@gmail.com

1 Department of Civil Engineering, MNNIT Allahabad, Prayagraj 211004, India as the $30^{\circ}$ slope, which is marginally stable under maximum rainfall intensity for the period 2015-2050 having factor of safety (FOS) value 1.0013, will fail under the maximum rainfall intensity for the period 2051-2075 and 2076-2100 having FOS value 0.9935 and 0.9989 , respectively. A continuous decrease in FOS with increasing rainfall intensity is observed for all the study areas under consideration.

Keywords Climate change - Factor of safety ·

Matric suction - Numerical modeling .

Saturated hydraulic conductivity · Transient seepage .

Unsaturated soil

\section{Introduction}

Slope failure or landslides are a natural phenomenon worldwide which endanger lives and cause damage to property. The slope failure can occur due to several reasons like steepening of slopes, earthquake, surface erosion, rainfall infiltration, deforestation, etc. Among all these factors, rainfall infiltration is considered to be the most frequent reason of landslides, especially in tropical regions. This is because, in tropical regions, rainfall continues for a longer period of time and in hilly areas, the soil cover over bedrocks is generally of a residual soil or colluvium soil having a relatively higher value of matric suction above ground water table.

Landslides due to rainfall are frequently occurred hazards in a tropical country like India. It was observed from past studies that $15 \%$ of landmass of India is susceptible to landslides which are near about 0.49 million sq. km [1]. Looking back into history of rainfall-induced landslides in India, there are a number of cases out of which some 
catastrophic landslides are slope failure along Mandakini valley in Okhimath (1998), Malpa rockfall (1998), Agastyamuni (2005), Balia Nala landslide in Nainital (2014), Kedarnath (2013), Malin landslide (2014), Shillong (2019), Kalimpong (2015), Marapallam, Nilgiris (2009), etc. [2-9].

These slope failures can be categorized as deep-seated landslides and shallow landslides. Deep-seated landslide involves the movement of surficial mantle and bedrock up to a greater depth, whereas this movement is few meters thick for shallow landslides. Generally occurred landslides are of shallow nature as deep-seated landslides are sensitive to extremes in hydraulic cycle and prolonged drought, which hindered the ground water recharge and hence lead to termination of this kind of landslides, whereas the occurrence of shallow landslide is sensitive to climatic factors like antecedent rainfall, swift snowmelt, extreme rainfall event, etc. These shallow landslides can occur due to any of the two failure mechanism, which are the diffused failure mechanism (occur in soil with undrained or partially drained condition having loose structure) and localized failure mechanism (occur in soil with drained condition) [10]. These landslide processes are estimated at local to regional scales.

A lot of studies on rainfall triggered slope instability have been reported in literature which is initially based on the assumption of considering soil in a saturated state and ignoring the role of matric suction in slope stability. Generally, the hill slopes in tropical regions are in unsaturated condition having a certain value of matric suction which provides an additional strength to soil by holding fine particles in a closer contact and providing an additional cohesion to soil particles. So these unsaturated slopes were started to be analyzed by an integrated unsaturated-saturated soil system.

It is well known that climate is changing with time and affecting environmental condition to a considerable extent. According to several researchers, this drastic change in climate is because of global warming which turns out to be a prime concern globally [11-14]. To have knowledge of changing climate and lead a battle against it through researches, IPCC (Intergovernmental Panel on Climate Change) was established in 1988. As per IPCC, the global average surface temperature is anticipated to be raised by $1.4{ }^{\circ} \mathrm{C}$ to $5.8^{\circ} \mathrm{C}$ by the period of 1990 to 2100 . Due to this rise in temperature over time, the rainfall patterns will not be the same always and it will turn into more intense and less frequent rainfall patterns. This variation in rainfall patterns can have gigantic impacts on soil moisture, groundwater and consequently affecting the strength of soil. The rainfall acts as a surface flux boundary condition, and with changing climate, it will also change, resulting in different pore water pressure conditions within the soil matrix.

Numerous researches have been conducted to investigate the effect of rainfall infiltration on slope stability which uses different infiltration models and limit equilibrium analysis for slope stability [15, 16]. Rainfall-induced instability for natural slopes in Singapore was investigated, and it was observed that the slope stability was affected by antecedent rainfall [17], whereas the observation of Hong Kong slopes shows that the effect of antecedent rainfall on slope stability was not significant [18]. This difference in conclusions was sorted by explaining the effect of hydraulic conductivity, as the type of soil in Hong Kong is having higher value of hydraulic conductivity than the soil in Singapore [17]. Past studies shows by parametric studies that rainfall intensity and properties of soil are the prime factors whereas geometry of slope and initial ground water table are secondary factors which affect slope stability [19].

To understand the failure mechanism of slopes due to infiltration of rain water, numerical simulations were carried out by different methods like limit equilibrium method (LEM), finite element method (FEM), finite difference method (FDM), boundary element method (BEM), neural networks, etc. Out of these methods, FEM and FDM give more accurate results as stress distributions and displacement of slope are also addressed in these methods which is not facilitated by LEM; but still LEM is the widely used method for slope stability analysis due to its simplicity and feasibility. Different software were used for analyzing slope stability which are transient rainfall infiltration and grid-based regional slope stability (TRIGRS), Geostudio (SEEP/W and SLOPE/W programs) [6, 11-13, 15-17, 19] Rock Science $\operatorname{RS}^{2}$ [14, 20], PLAXIS [21], FLAC (Fast Lagrangian Analysis of Continua) [5, 7, 9], etc. Out of all these software, SEEP/W and SLOPE/W programs of Geostudio 2018 R2 are used for seepage and slope stability analysis, respectively, as a transient rainfall infiltration analysis with corresponding factor of safety evaluation makes it easier to continuously analyze the slope stability from soil in unsaturated state to saturated state with its flexibility regarding geometry.

To reduce the adverse consequences, slope failures have to be pre-detected. Several researchers analyzed this slope instability problem but they generally considered a stationary approach for extracting rainfall data [11]. However, with changing climate, the rainfall extremes are changing with time resulting in more intense rainfall resting for a longer duration which demands for analysis based on nonstationary approaches $[14,20]$. These analyses are of prime importance as it can serve as a basis for evaluation of potentially unstable slopes which are prone to failure due to a change in surface flux boundary condition with time, so 
that the risk of lives and property damage will be avoided up to a certain extent. This can help us on societal, as well as economic, level.

Hence, in this study, a changing statistics of extremes are considered by analyzing the stability of slope under current as well as future scenarios by considering 95 percentile rainfall intensity and maximum rainfall intensity for three time durations which are 2015-2050, 2051-2075 and 2076-2100, and these data are extracted from CMIP5 climate model, which is then analyzed for seepage and stability of slopes by SEEP/W and SLOPE/W programs of Geostudio 2018 R2 software, respectively.

The objective of this study is as follows:

- To analyze transient seepage into soil slopes of different regions (Assam, Uttarakhand and Nilgiri) due to rainfall infiltration;

- To analyze slope stability corresponding to transient seepage due to rainfall infiltration;

- To check the effect of changing climate due to global warming on slope stability.

\section{Study Areas and Input Parameters}

The hilly regions of Himalayas, Western Ghats, Nilgiris and Northeastern region of India are the most vulnerable areas which are prone to landslides due to rainfall infiltration [22]. In this study, following three study areas from the above regions are taken for analysis by considering general slope geometry, soil hydraulic properties and strength properties.

\section{Haflong, Assam (A Part of North-Eastern Region of India)}

Most of the hill slopes of Assam consist of different type of residual soils which are formed by weathering of basalt rock, granitic rock or the soil overburden may be of saprolitic and lateritic residual soil [1]. Haflong is the head quarter of Dima Hasao district in Assam, India (Fig. 1). Its location coordinates are $25.3478^{\circ} \mathrm{N} 93.01176^{\circ} \mathrm{E}$. It is having subtropical climate condition which causes heavy rainfall in this area, and the landslides occurred due to this heavy rainfall affected daily life of people. The soil of hill slopes of Haflong is generally classified as low compressibility clay (CL) [13], and this study takes two different slope angles (Fig. 2) into consideration with soil hydraulic and strength properties shown in Table 1. Rainfall infiltration within the soil mass is dependent on SWCC and $\mathrm{HCF}$ of soil which are shown in Fig. 3 for Haflong soil.

\section{Uttarakhand (A Part of Northern Himalayan Region of India)}

In Lesser Himalayan region tectonic activities, diverse geological conditions and structural distortions along main boundary thrust (MBT) cause movement of soil/rock slopes and led to massive destruction in the past. It was observed that certain soil/rock types which absorb abundance of moisture are rather easy to deform [23]. Quartzite, limestone, slates, silty sandstone, gneiss, schist, phyllite, etc., are the rock types in hilly region of Uttarakhand, which are generally weathered up to a certain depth forming soils that are generally sandy soil, sandy loam soil and silt loam soils. The area under consideration is the Birahi vally catchment (Garigaon watershed) in Chamoli district of Uttarakhand (Fig. 4). This area is enclosed by $30^{\circ} 21^{\prime} 7^{\prime \prime} \mathrm{N}$ to $30^{\circ} 23^{\prime} 11^{\prime \prime}$ latitude and $79^{\circ} 23^{\prime} 18 \mathrm{E}$ to $79^{\circ} 25^{\prime} 30^{\prime \prime} \mathrm{E}$ longitude [24]. The natural slopes range from $40^{\circ}$ to $60^{\circ}$, and the cut slopes are generally $60^{\circ}$ to $80^{\circ}$ in this region. Considering a general value between the specified ranges, this analysis is performed for a $20 \mathrm{~m}$ high slope with slope angle $60^{\circ}$ (Fig. 8a) and the soils taken for analysis are sandy loam and silt loam soil of this area which are taken as per Mathew et al. [24]. The hydraulic properties (SWCC and HCF are shown in Fig. 5) and strength properties of these soils are listed in Table 2.

\section{Tamilnadu}

Nilgiri district in Tamilnadu is the frequent rain-induced landslide affected part of Western Ghats. Its location is at the tri-junction of Karnataka, Kerala and Tamilnadu (Fig. 6). This hilly district is situated at an elevation of $1000 \mathrm{~m}$ to $2633 \mathrm{~m}$ above MSL (Mean sea level) [25]. This district is having undulated topography having a variation in slope angles from $15^{\circ}$ to $60^{\circ}$. The Archean metamorphic rocks Charnockite and Gniess are generally found in this area, and these bedrocks were generally underlain by reddish brown and yellowish laterite soil (residual soils formed by intense weathering) having varying thickness from 1 to $30 \mathrm{~m}$ [9]. In this study, a sandy silt slope with its hydraulic (SWCC and HCF shown in Fig. 7) and strength properties shown in Table 3 is considered for analysis. A general slope profile of $20 \mathrm{~m}$ height and $35^{\circ}$ slope angle (Fig. 8b) is considered for the analysis of seepage due to rainfall and its corresponding effect on slope stability.

\section{Methodology}

The methodology for this study comprises of three steps: rainfall data extraction, seepage analysis and stability analysis. 

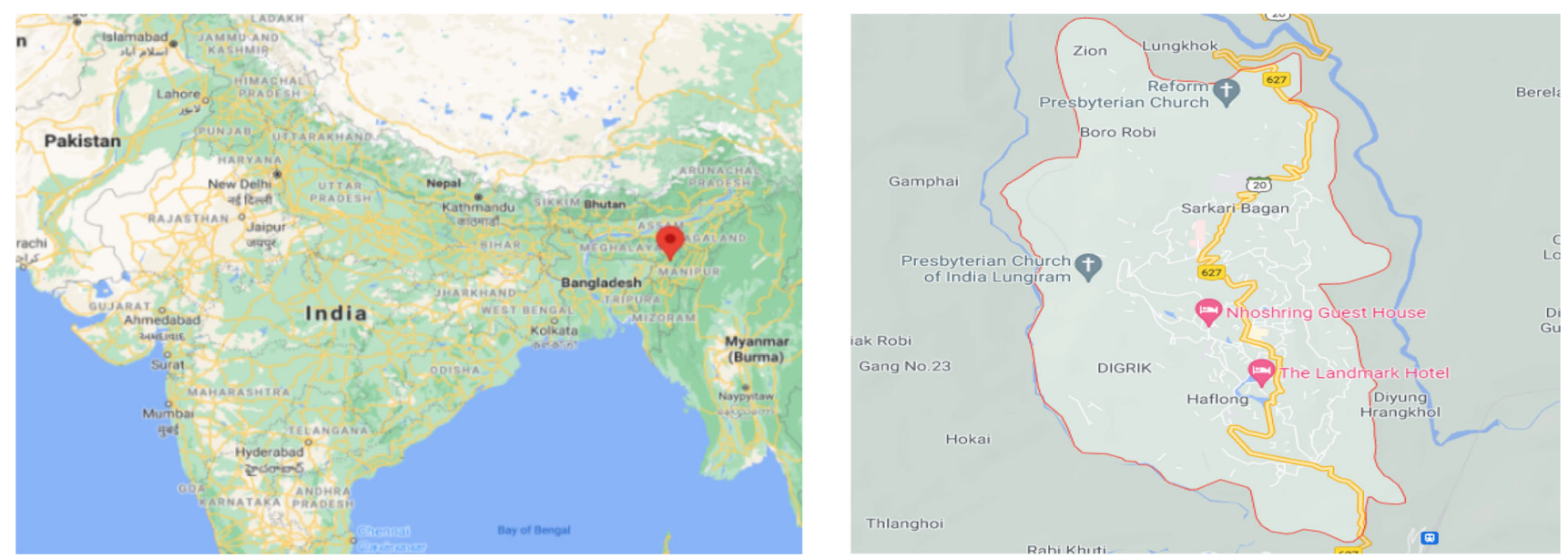

Fig. 1 Geographical location of Haflong, Assam ( Source: Google Maps)
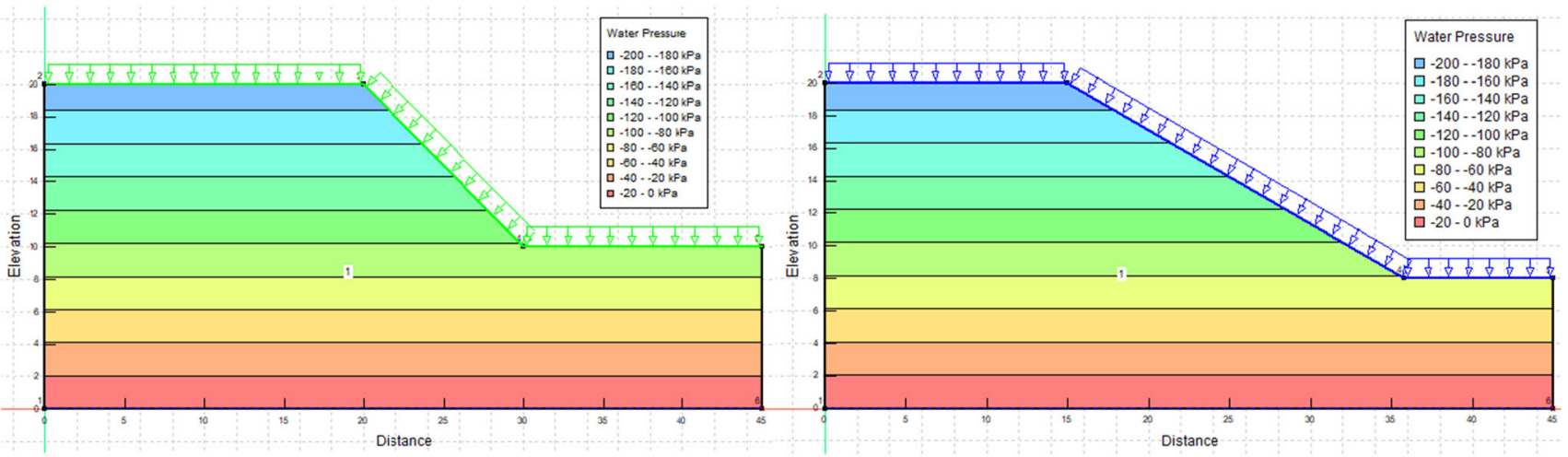

Fig. 2 General slope profile for Haflong region for $30^{\circ}$ and $45^{\circ}$ slope angle

Table 1 Input parameters for SEEP/W and SLOPE/W programs for Haflong clayey soil [13]

\begin{tabular}{lll}
\hline S. no & Parameters & Values \\
\hline 1 & Unit weight $(\gamma)$ & $26 \mathrm{kN} / \mathrm{m}^{3}$ \\
2 & Cohesion $\left(c^{\prime}\right)$ & $30 \mathrm{kPa}$ \\
3 & Angle of internal friction $\left(\phi^{\prime}\right)$ & $8^{\circ}$ \\
4 & Saturated volumetric water content $\left(\theta_{\mathrm{s}}\right)$ & 0.346 \\
5 & Residual volumetric water content $\left(\theta_{\mathrm{r}}\right)$ & 0.05 \\
6 & Saturated hydraulic conductivity $\left(k_{\mathrm{s}}\right)$ & $1.39 \times 10^{-5} \mathrm{~m} /$ \\
& & $\mathrm{s}$ \\
7 & $D_{60}$ & $0.095 \mathrm{~mm}$ \\
8 & $D_{30}$ & $0.0044 \mathrm{~mm}$ \\
9 & Liquid limit & $30 \%$ \\
10 & Soil classification (USCS) & $\mathrm{CL}$ \\
11 & Height of slope & $10 \mathrm{~m}$ \\
12 & Slope angle & $30^{\circ}$ and $45^{\circ}$ \\
13 & Maximum negative pore water pressure & 200 \\
& (kPa) & \\
\hline
\end{tabular}

In this study, a changing statistics of extremes is considered by analyzing the stability of slope under current as well as future scenarios by considering rainfall patterns for three time durations which are 2015-2050, 2051-2075 and 2076-2100. The slopes are analyzed under maximum rainfall intensity (to check the stability of slope under extreme rainfall events) and $95 \%$ rainfall intensity $(i=$ mean rainfall intensity $+2 \times$ standard deviation) (Table 4). Rather than using different climate models, the rainfall simulations available from the CMIP5 (Coupled model intercomparision project phase 5) with RCP8.5 (representative concentration pathway), i.e., future with no climate action are selected as inputs for the analysis in which the rainfall intensity value represents an ensemble mean (average of multiple quantitative climate model projections for a given climate variable). These precipitation estimates that are obtained from CMIP5 simulations promote a standard set of model simulations in order to:

- Evaluate how pragmatic these models are in simulating the recent past, and

- Provide projections of changing climate in future 
(a)

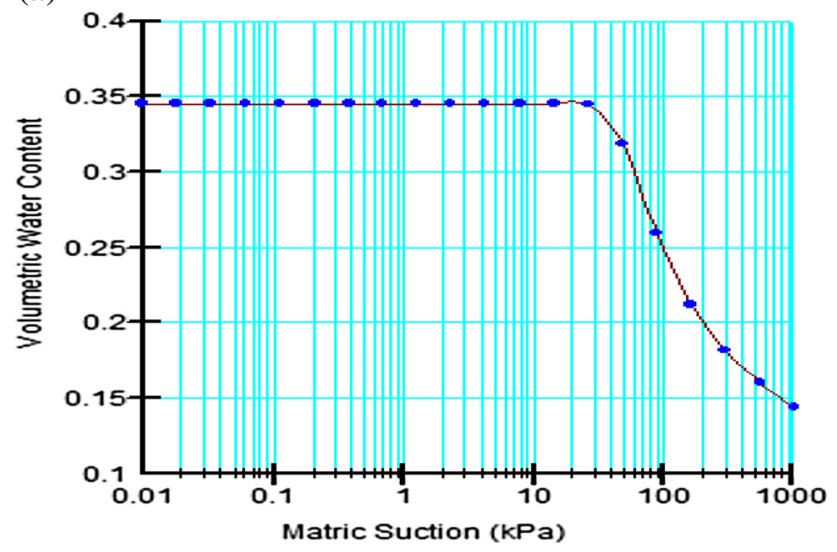

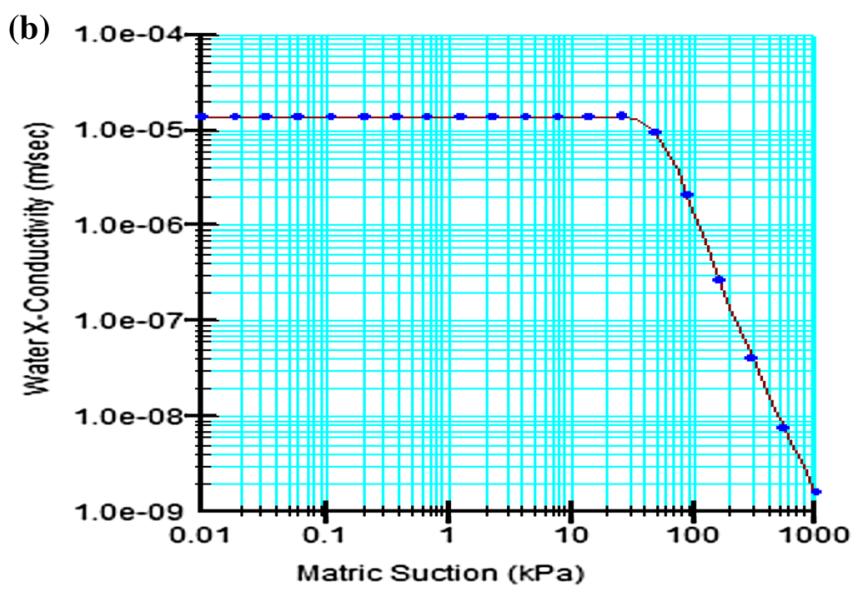

Fig. 3 a Soil water characteristic curve (SWCC); and b Hydraulic conductivity function (HCF) for Haflong soil
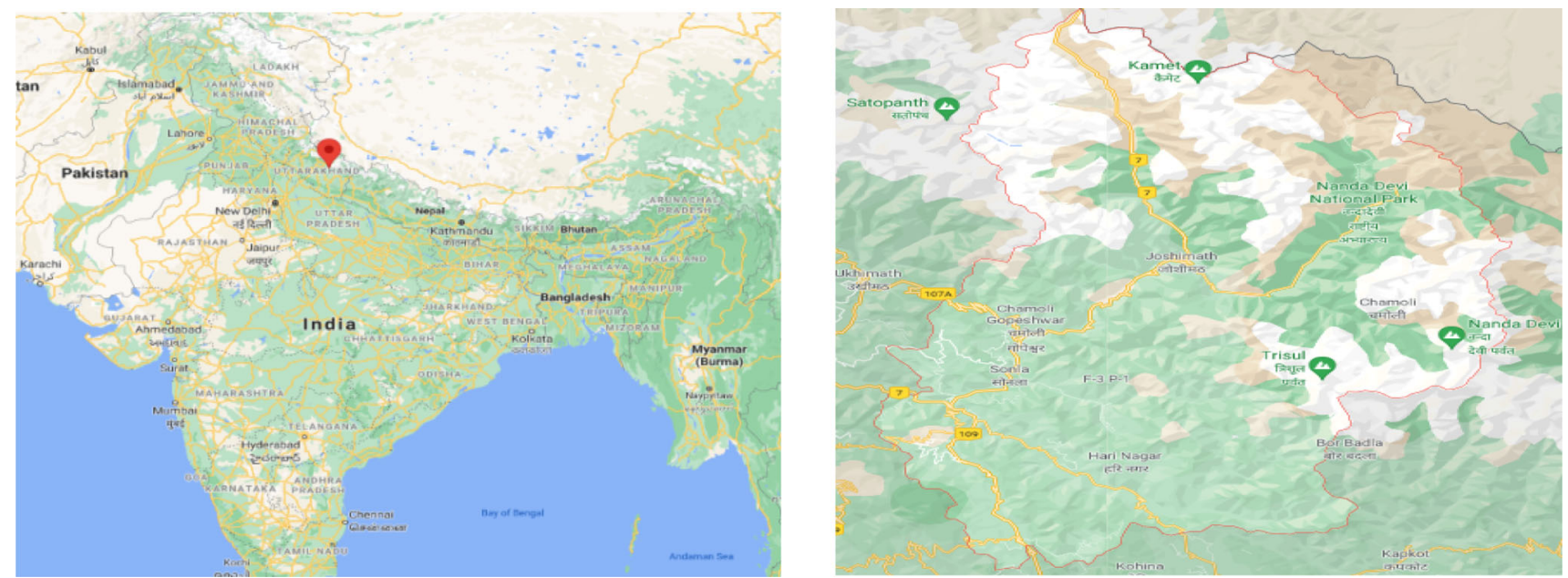

Fig. 4 Geographical location of Chamoli, Uttarakhand (Source: Google Maps)
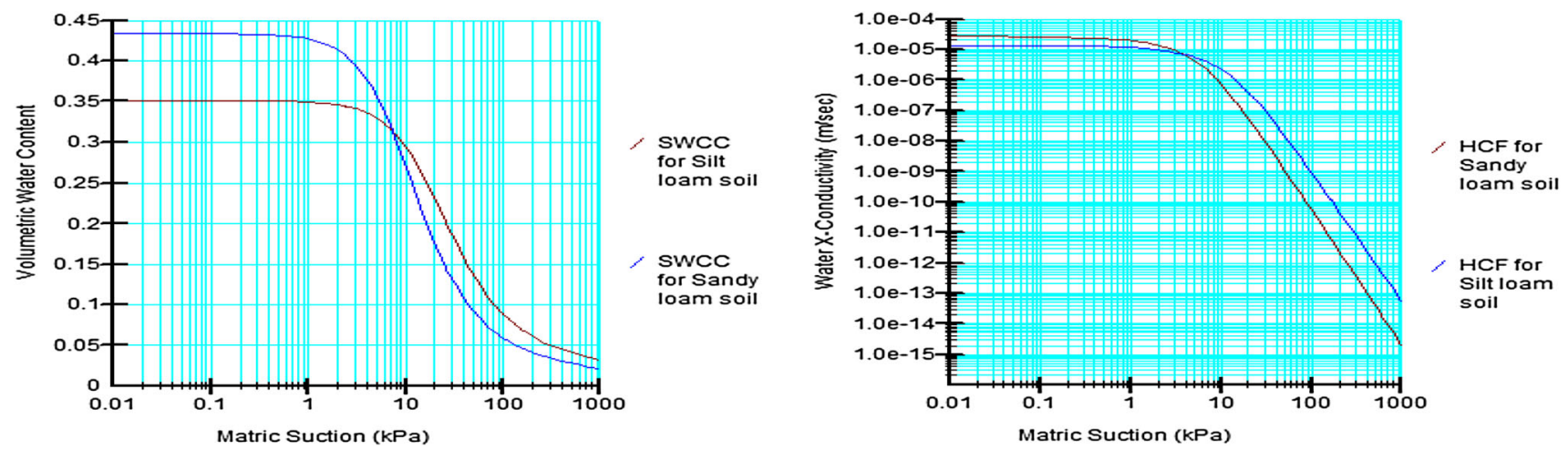

Fig. 5 SWCC and HCF for sandy loam and silt loam soils of Uttarakhand

\section{Seepage Analysis}

In this study, an unsaturated/saturated transient seepage analysis is performed with SEEP/W computer program of Geostudio 2018 R2 software [26]. The analysis is performed for 5 days with the rainfall duration of first $24 \mathrm{~h}$ and the initial condition for the analysis is represented by the location of initial ground water table with an assigned maximum negative pore water pressure head, so that the analysis can be performed in a more realistic way. 
Table 2 Input parameters for SEEP/W and SLOPE/W program for soils of Uttarakhand [24]

\begin{tabular}{llll}
\hline S. No & Parameters & Sandy loam & Silt loam \\
\hline 1 & Unit weight $(\gamma)$ & $14.8 \mathrm{kN} / \mathrm{m}^{3}$ & $16.87 \mathrm{kN} / \mathrm{m}^{3}$ \\
2 & Effective cohesion $\left(c^{\prime}\right)$ & $7.358 \mathrm{kPa}$ & $8.339 \mathrm{kPa}$ \\
3 & Effective angle of internal friction $\left(\phi^{\prime}\right)$ & $36^{\circ}$ & $38^{\circ}$ \\
4 & Saturated volumetric water content $\left(\theta_{\mathrm{s}}\right)$ & 0.434 & 0.351 \\
5 & Residual volumetric water content & 0.043 & 0.035 \\
6 & Saturated hydraulic conductivity $\left(k_{\mathrm{s}}\right)$ & $2.61 \times 10^{-5} \mathrm{~m} / \mathrm{s}$ & $1.382 \times 10^{-5} \mathrm{~m} / \mathrm{s}$ \\
7 & Soil classification (USCS) & Silty sand $(\mathrm{SM})$ & Silt $(\mathrm{ML})$ \\
8 & Height of slope (m) & 10 & 10 \\
9 & Slope angle & $60^{\circ}$ & $60^{\circ}$ \\
10 & Maximum negative pore water pressure & $50 \mathrm{kPa}$ & $50 \mathrm{kPa}$ \\
\hline
\end{tabular}
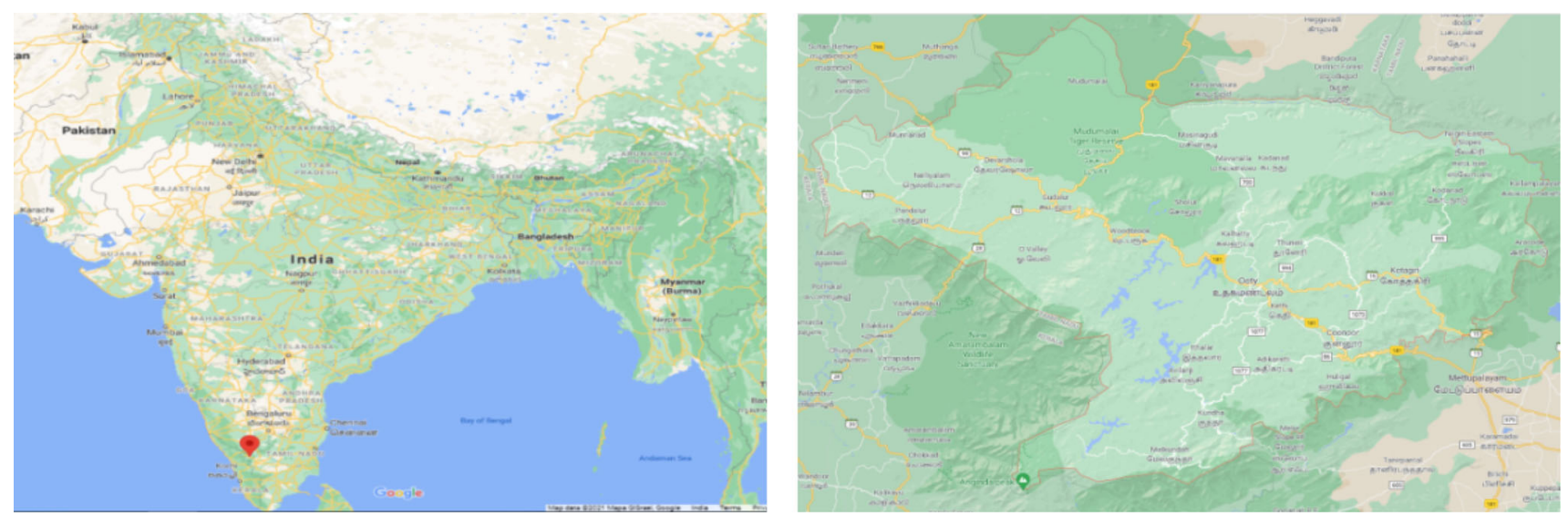

Fig. 6 Geographical location of Nilgiri, Tamilnadu ( Source: Google Maps)
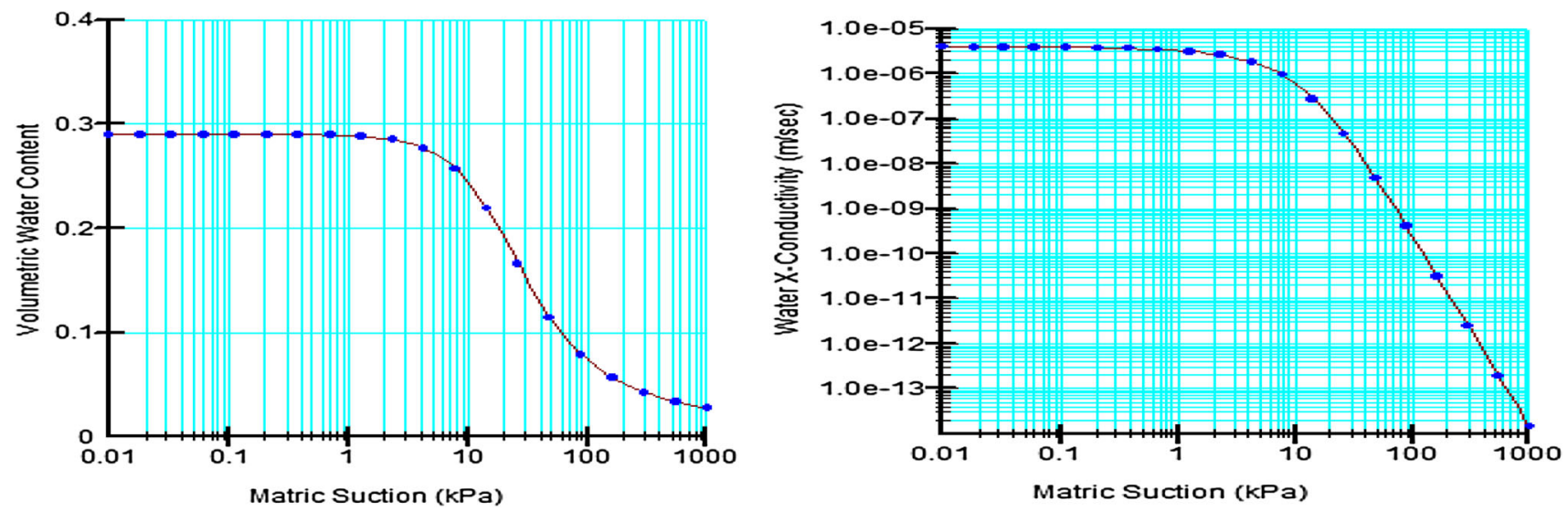

Fig. 7 SWCC and HCF for sandy silt soil of Nilgiri hills (Tamilnadu)

The transient SEEP/W program is based on Darcy's law which is represented as follows:

$q=k i$ where $q$ is specific discharge, $i$ refers to hydraulic gradient and $k$ is hydraulic conductivity of soil.

This equation is valid for both saturated and unsaturated conditions with the only difference that hydraulic conductivity is not constant in unsaturated condition and 
Table 3 Input parameters for SEEP/W and SLOPE/W program for soil of Nilgiri hills [9]

\begin{tabular}{lll}
\hline S. & Parameters & Values \\
No & & \\
\hline 1 & Unit weight $(\gamma)$ & $20.05 \mathrm{kN} / \mathrm{m}^{3}$ \\
2 & Cohesion $\left(c^{\prime}\right)$ & $15 \mathrm{kPa}$ \\
3 & Angle of internal friction $\left(\phi^{\prime}\right)$ & $27^{\circ}$ \\
4 & Saturated volumetric water content $\left(\theta_{\mathrm{s}}\right)$ & 0.29 \\
5 & Residual volumetric water content $\left(\theta_{\mathrm{r}}\right)$ & 0.029 \\
6 & Saturated hydraulic conductivity $\left(k_{\mathrm{s}}\right)$ & $3.924 \times 10^{-6} \mathrm{~m} /$ \\
& & $\mathrm{s}$ \\
7 & Soil classification (USCS) & Sandy silt \\
8 & Height of slope & $20 \mathrm{~m}$ \\
9 & Slope angle & $35^{\circ}$ \\
10 & Maximum negative pore water pressure & 15 \\
& $(\mathrm{kPa})$ & \\
\hline
\end{tabular}

changes with water content of soil. For two-dimensional seepage, the general governing differential equation is defined as follows [12]: $\frac{\partial}{\partial x}\left(k_{x} \frac{\partial H}{\partial x}\right)+\frac{\partial}{\partial y}\left(k_{y} \frac{\partial H}{\partial y}\right)+Q=\frac{\partial \theta}{\partial t}$

where $H$ is the total head, $k_{x}$ and $k_{y}$ are hydraulic conductivity in $x$ and $y$ direction, $Q$ is applied boundary flux, $\theta$ is volumetric water content and $t$ is time.

For transient condition, the pore air pressure is considered to be constant at atmospheric pressure. So the change in volumetric water content is governed by pore water pressure $\left(u_{w}\right)$. Hence, the equation used in SEEP/ $W$ finite element computer program is reduced in the following form [12]:

$\frac{\partial}{\partial x}\left(k_{x} \frac{\partial H}{\partial x}\right)+\frac{\partial}{\partial y}\left(k_{y} \frac{\partial H}{\partial y}\right)+Q=m_{w} \gamma_{w} \frac{\partial H}{\partial t}$

where $m_{w}$ is the slope of storage curve.

Prior to seepage analysis, material or soil properties and boundary conditions have to be defined. The soil properties are defined by volumetric water content (VWC) function or SWCC (soil water characteristic curve) and HCF (Hydraulic conductivity function) considering unsaturated/ (a)

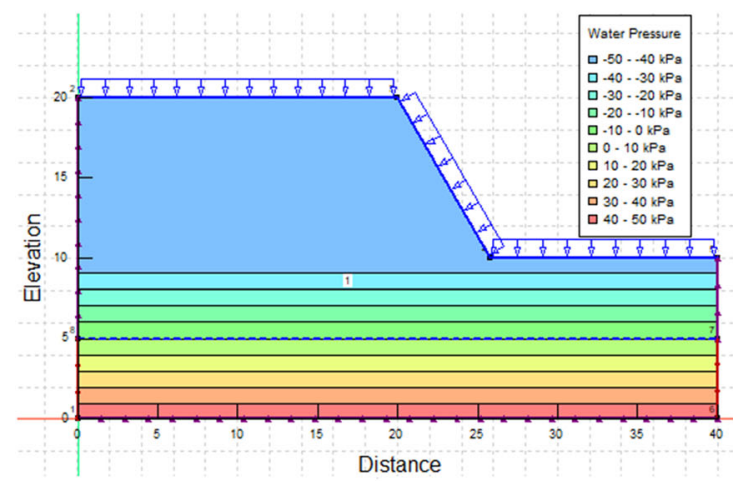

(b)

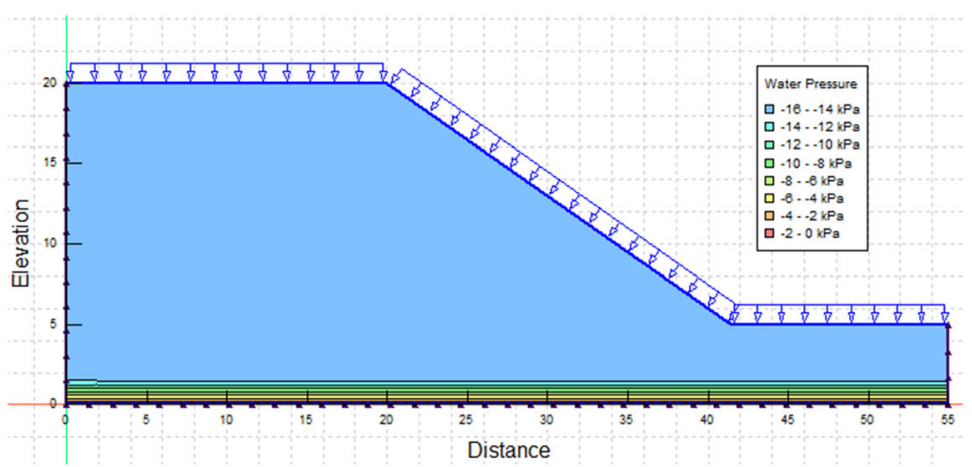

Fig. 8 General slope profile for a Uttarakhand; and b Tamilnadu region

Table 4 Rainfall data for different landslide prone regions of India

\begin{tabular}{llllll}
\hline Study area & $\begin{array}{l}\text { Period of } \\
\text { analysis }\end{array}$ & $\begin{array}{l}95 \text { percentile rainfall } \\
\text { intensity }(\mathrm{mm} / \mathrm{hr})\end{array}$ & $\begin{array}{l}95 \text { percentile rainfall } \\
\text { intensity }(\mathrm{m} / \mathrm{s})\end{array}$ & $\begin{array}{l}\text { Maximum rainfall } \\
\text { intensity }(\mathrm{mm} / \mathrm{hr})\end{array}$ & $\begin{array}{l}\text { Maximum rainfall } \\
\text { intensity }(\mathrm{m} / \mathrm{s})\end{array}$ \\
\hline Haflong & $2015-2050$ & 9.8 & $2.72 \times 10^{-6}$ & 53.48 & $1.49 \times 10^{-5}$ \\
$\quad$ (Assam) & $2051-2075$ & 10.57 & $2.94 \times 10^{-6}$ & 56.07 & $1.56 \times 10^{-5}$ \\
& $2076-2100$ & 11.17 & $3.1 \times 10^{-6}$ & 54.12 & $1.5 \times 10^{-5}$ \\
Chamoli & $2015-2050$ & 8.4 & $2.33 \times 10^{-6}$ & 52.02 & $1.445 \times 10^{-5}$ \\
$\quad$ (Uttarakhand) & $2051-2075$ & 9.15 & $2.542 \times 10^{-6}$ & 48.93 & $1.359 \times 10^{-5}$ \\
& $2076-2100$ & 10.25 & $2.847 \times 10^{-6}$ & 65.45 & $1.82 \times 10^{-5}$ \\
Nilgiri & $2015-2050$ & 8.68 & $2.41 \times 10^{-6}$ & 44.12 & $1.226 \times 10^{-5}$ \\
(Tamilnadu) & $2051-2075$ & 9.7 & $2.69 \times 10^{-6}$ & 45.34 & $1.259 \times 10^{-5}$ \\
& $2076-2100$ & 11.54 & $3.206 \times 10^{-6}$ & 59.98 & $1.67 \times 10^{-5}$ \\
\hline
\end{tabular}


saturated material model. Volumetric water content function can be defined by using any of the four functions inbuilt in Geostudio software, which are VWC data point function, Sample functions, Van Genuchten function and Fredlund-Xing function. Out of these, data point function (Table 1) and sample functions (Tables 2 and 3) are used in this study.

Other than these two functions, a closed form solution was proposed by Van Genuchten in 1980 for developing soil water characteristic curve, which is governed by the following equation [27]:

$\theta_{w}=\theta_{r}+\frac{\theta_{s}-\theta_{r}}{\left[1+\left(\frac{\Psi}{a}\right)^{n}\right]^{m}}$

And an another closed form solution was proposed by Fredlund-Xing in 1994 which is used to develop SWCC for all negative pore water pressure values between zero and 1 million $\mathrm{kPa}$ based on three parameters. Its relation is expressed as [28] follows:

$\theta_{w}=C_{\Psi} \theta_{\mathrm{s}}\left[\frac{1}{\ln \left\{e+\left(\frac{\Psi}{a}\right)^{n}\right\}}\right]^{m}$

where $\theta_{\mathrm{w}}, \theta_{s}$ and $\theta_{\mathrm{r}}$ are natural volumetric water content, saturated volumetric water content and residual volumetric water content, $\psi$ is negative pore water pressure or matric suction and $a, n, \mathrm{~m}$ are the curve fitting parameters (in Van Genuchten equation, $[n=1 / 1-m]$ )

Here, $\mathrm{a}$ is the pivot point about which parameter $n$ changes slope of function (in $\mathrm{kPa}$ ) and $\mathrm{m}$ is that parameters which affects the sharpness of sloping portion of curve as it enters the lower plateau [27]; whereas a (in $\mathrm{kPa}$ ) refers to the inflection point of SWCC and its value in general is slightly higher than air entry value. Here, parameter $\mathrm{m}$ controls residual water content and parameter $\mathrm{n}$ controls the slope of SWCC [28].

SEEP/W uses two different models which are built into the software and are used for prediction of unsaturated hydraulic conductivity. These two models used soil water characteristic curve as input derived either from Van Genuchten equation or Fredlund-Xing equation which are built in software as hydraulic data point functions. The closed form equation derived by Van Genuchten and Mualem for analyzing hydraulic conductivity function needs SWCC as input along with the value of saturated hydraulic conductivity $\left(k_{s}\right)$, saturated volumetric water content $\left(\theta_{\mathrm{s}}\right)$ and residual volumetric water content $\left(\theta_{\mathrm{r}}\right)$. This equation is expressed as follows [27]:

$k_{w}=k_{s} \frac{\left[1-\left(a \Psi^{n-1}\right)\left(1+\left(a \Psi^{n}\right)^{-m}\right]^{2}\right.}{\left[\left\{(1+a \Psi)^{n}\right\}^{\frac{m}{2}}\right]}$ where $k_{s}$ is saturated hydraulic conductivity and the other parameters are same as expressed in Van Genuchten equation.

The equation for the derivation of hydraulic conductivity function of soils used in SEEP/W which uses Fredlund-Xing equation as input is expressed as follows [28]; $k_{w}=k_{s} \Theta^{p}$

where $k_{w}=$ hydraulic conductivity with respect to water for unsaturated soil, $k_{s}$ is saturated hydraulic conductivity, $p$ is fitting parameter corresponding to slope of HCF and $\Theta$ is dimensionless form of SWCC $\left\{\Theta=\left(\theta_{\mathrm{w}} / \theta_{\mathrm{s}}\right)\right\}$.

The boundary conditions applied as follows on the geometry of slope:

- Rainfall intensity is applied as a flux boundary condition on the surface of the slope;

- Below ground water table, total head boundary condition is applied on the sides of slope; and

- Above ground water table, nodal flux $Q=0 \mathrm{~m}^{3} / \mathrm{c}$ is applied on the sides of slope representing no flow boundary condition.

\section{Slope Stability Analysis}

The results obtained from seepage analysis in the form of pore water pressure distribution are used as input in SLOPE/W computer program [29]. The unsaturated shear strength is derived through Geostudio SLOPE/W program using Mohr-Coulomb failure model, which offers two ways to model the effect of matric suction on shear strength of soil [12].

In the first method, an angle defines increase in strength due to matric suction $\left(\phi_{\mathrm{b}}\right)$ to compute the mobilized shear stress at the base of slice. When this method is used in SLOPE/W, it utilizes the following equation [12]:

$\tau=c^{\prime}+\left(\sigma_{n}-u_{a}\right) \tan \varphi^{\prime}+\left(u_{a}-u_{w}\right) \tan \varphi^{b}$

where $c^{\prime}$ is effective cohesion, $\sigma_{n}$ is total normal stress, $u_{w}$ is pore water pressure, $u_{a}$ is pore air pressure, $\phi^{\prime}$ is effective friction angle and $\phi_{\mathrm{b}}$ is the angle defining increase in strength due to matric suction (generally taken equal to $\phi^{\prime} /$ 2).

In this equation, a constant value of $\phi_{\mathrm{b}}$ is considered, whereas this value changes with degree of saturation as for the capillary saturated zone $\phi_{\mathrm{b}}$ is equal to $\phi^{\prime}$ (effective friction angle) and it decreases as the soil became saturated. So it can be said that $\phi_{\mathrm{b}}$ is related to volumetric water content function or SWCC. Hence, another method is proposed by Vanapalli et al. (1996) which utilizes relation between $\phi_{\mathrm{b}}$ and SWCC. The equation is expressed as follows [12]: 


$$
\tau=c^{\prime}+\left(\sigma_{n}-u_{a}\right) \tan \varphi^{\prime}+\left(u_{a}-u_{w}\right)\left[\left(\frac{\theta_{w}-\theta_{r}}{\theta_{s}-\theta_{r}}\right) \tan \varphi^{\prime}\right]
$$

Now factor of safety is calculated by

$$
\mathrm{FOS}=\frac{\sum \tau_{r}}{\sum \tau_{m}}
$$

Here, $\tau_{\mathrm{r}}$ represents resisting shear stresses and $\tau_{\mathrm{m}}$ represents mobilized shear stresses.

In SLOPE/W program, the slope stability can be performed by four limit equilibrium methods, which are different in handling inter-slice forces. The Morgenstern and Price method gives a relation between inter-slice forces, and it satisfied both moment and force equilibrium equation. Janbu's simplified method is based on the assumption that inter-slice forces are horizontal but satisfied only force equilibrium equations. Fellinius method is based on the assumption that there is no inter-slice forces and it satisfied only moment equilibrium equation. The Bishop's simplified method also assumed horizontal inter-slice forces, and it satisfied moment equilibrium equation only. In this study, Morgenstern and Price method is used with MohrCoulomb failure criterion for slope stability analysis as [30]

- It considers both normal and shear inter-slice forces;

- It assumes an inter-slice force function which continuously varies along the slip surface; and

- It computes factor of safety for both force equilibrium and moment equilibrium.

\section{Results and Discussion}

The results are expressed in the form of change in pore water pressure distribution within the soil with time, change in FOS with time and relative changes in FOS for the period of 2051-2075 and 2076-2100 when compared to the factor of safety for the period 2015-2050. Based on these results, a parametric study is also performed which explains about the dependency of pore water pressure changes and corresponding change in factor of safety on slope properties, soil properties and rainfall intensity.

\section{Haflong (Assam, India)}

The analysis is performed for a particular CL (clay with low compressibility) soil of slope having a constant height with two different slope angles. The results obtained are as follows.
Change in Pore Water Pressure with Time

The change in PWP with time is represented in Figs. 9 and 10 for Haflong soil at $30^{\circ}$ and $45^{\circ}$ slope angle, respectively. Due to high initial matric suction $(200 \mathrm{kPa})$, the PWP at ground surface is still having negative pore water pressure values even at the end of 1 day rainfall. Difference in PWP at different rainfall intensities for different duration of analysis is shown in Table 5. Hence, it is clear that reduction in matric suction will be more for $45^{\circ}$ slope as compared to $30^{\circ}$ slope.

\section{Change in Factor of Safety With Time}

Table 6 represents a comparison among FOS for both the slopes with $30^{\circ}$ and $45^{\circ}$ slope angle. In case of soil slope with $30^{\circ}$ slope angle, the percentage decrease in FOS from its initial value is about $2.942 \%, 3.688 \%$ and $3.967 \%$ at $95 \%$ rainfall intensity and $20.77 \%, 21.39 \%$ and $20.96 \%$ at maximum rainfall intensity for the period of analysis 2015-2050, 2051-2075 and 2076-2100, respectively (Figs. 11, 12). Also, the relative change in FOS for the period of 2051-2075 and 2076-2100 is $1.18 \%$ and $1.46 \%$, respectively, at $95 \%$ rainfall intensity and $0.77 \%$ and $0.235 \%$, respectively, at maximum rainfall intensity when compared to analysis period 2015-2050 for soil slope with $30^{\circ}$ slope angle, which shows the effect of climate change on slope stability. Whereas in case of $45^{\circ}$ angle slope, the percentage decrease in FOS from its initial value is about $4.76 \%, 4.97 \%$ and $5.19 \%$ at $95 \%$ rainfall intensity and about $22.04 \%, 23.16 \%$ and $22.3 \%$ at maximum rainfall intensity for analysis period 2015-2050, 2051-2075 and 2076-2100, respectively. The relative change in FOS for the period of 2051-2075 and 2076-2100 is $0.22 \%$ and $0.45 \%$, respectively, at $95 \%$ rainfall intensity and $1.44 \%$ and $0.33 \%$ at maximum rainfall intensity, respectively, when compared to 2015-2050 for soil slope with $45^{\circ}$ slope angle.

\section{Chamoli, Uttarakhand}

The results obtained by analyzing behavior of both the soils with commencement of rainfall and are expressed in the following way.

\section{Change in Pore Water Pressure with Time}

The change in PWP with time for sandy loam and silt loam soil is plotted in Figs. 13 and 14. It is noted that for sandy loam soil slope, the PWP became zero at soil surface after $7 \mathrm{~h}$ and $1 \mathrm{~h}$ of continuous rainfall for all three period of analysis at 95 percentile and maximum rainfall intensity, respectively. The relative change in PWP distribution is 
(a)

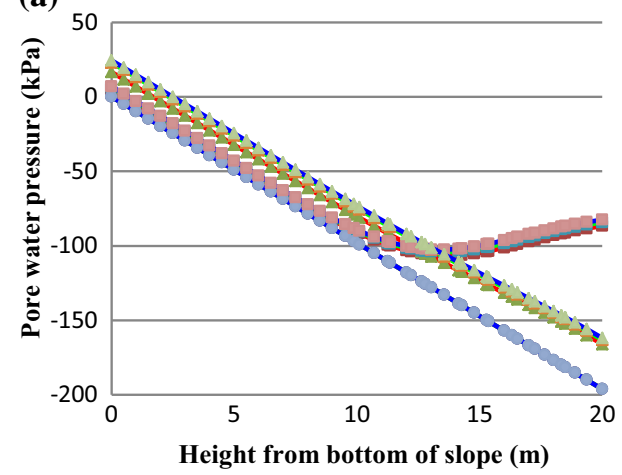

(b)

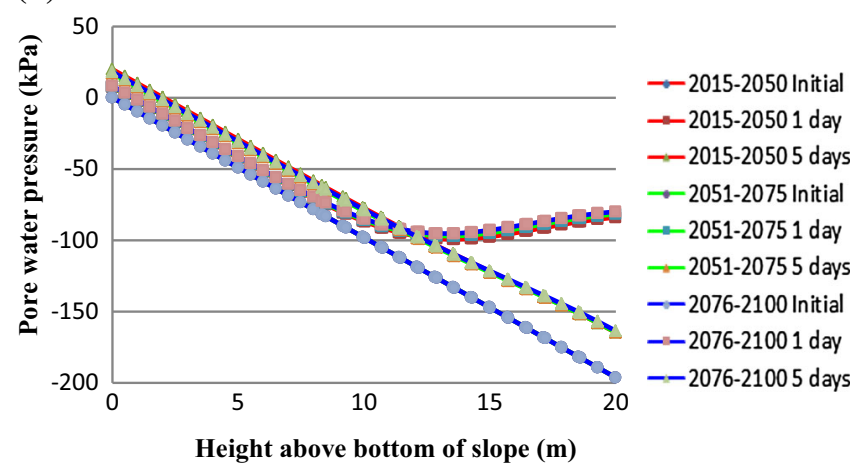

Fig. 9 PWP profiles for Haflong slope at $95 \%$ rainfall intensity a for $30^{\circ} \mathbf{b}$ for $45^{\circ}$ slope angle

(a)

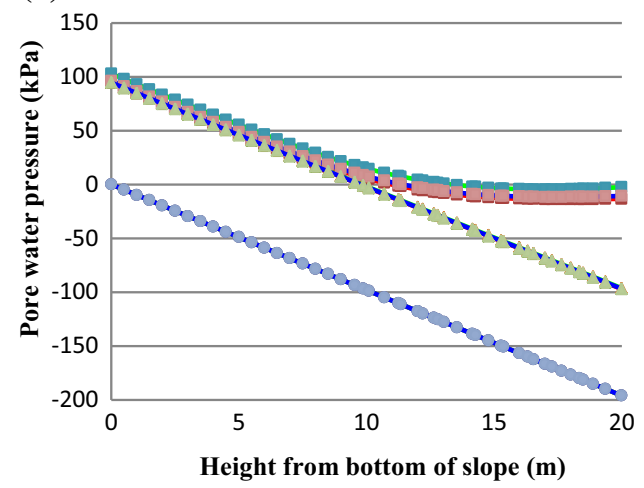

(b)

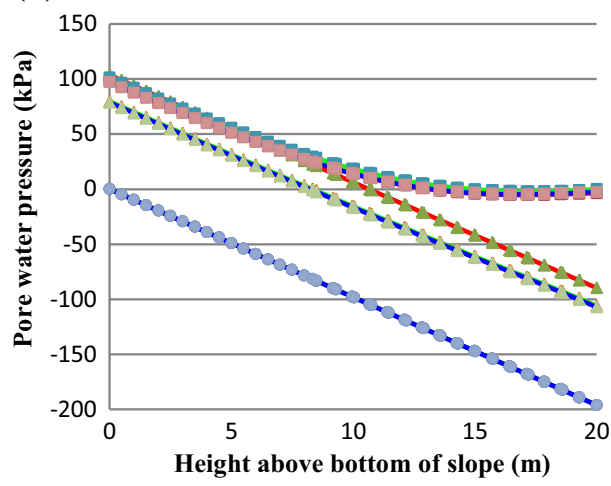

- 2015-2050 Initial $-2015-20501$ day $-2015-20505$ days $\rightarrow 2051-2075$ Initial $=-2051-20751 \mathrm{day}$ $\simeq$ 2051-2075 5 days - -2076-2100 Initial $-2076-21001 \mathrm{day}$ $-2076-21005$ days

Fig. 10 PWP profiles for Haflong at maximum rainfall intensity a for $30^{\circ} \mathbf{b}$ for $45^{\circ}$ slope angle

Table 5 Pore water pressure values at soil surface at the end of rainfall event for Haflong soil

\begin{tabular}{llllll}
\hline Period of analysis & \multicolumn{2}{l}{ For $30^{\circ}$ slope angle $(\mathrm{kPa})$} & & For $45^{\circ}$ slope angle $(\mathrm{kPa})$ \\
\cline { 2 - 3 } \cline { 5 - 6 } & At $95 \%$ rainfall intensity & At maximum rainfall intensity & At $95 \%$ rainfall intensity & At maximum rainfall intensity \\
\hline $2015-2050$ & -86.6437 & -13.3363 & -83.902 & -3.64666 \\
$2051-2075$ & -84.2373 & -2.58123 & -81.6133 & 0 \\
$2076-2100$ & -82.5179 & -10.7142 & -79.8985 & -2.61253 \\
\hline
\end{tabular}

Table 6 Initial and minimum factor of safety for Haflong soil at different slope angles

\begin{tabular}{|c|c|c|c|c|c|c|}
\hline \multirow{3}{*}{$\begin{array}{l}\text { Period of } \\
\text { analysis }\end{array}$} & \multicolumn{3}{|l|}{ For $30^{\circ}$ slope angle } & \multicolumn{3}{|l|}{ For $45^{\circ}$ slope angle } \\
\hline & \multirow{2}{*}{$\begin{array}{l}\text { Initial FOS } \\
\text { At } 95 \% \text { and maximum } \\
\text { rainfall intensity }\end{array}$} & \multicolumn{2}{|l|}{ Minimum FOS } & \multirow{2}{*}{$\begin{array}{l}\text { Initial FOS } \\
\text { At } 95 \% \text { and maximum } \\
\text { rainfall intensity }\end{array}$} & \multicolumn{2}{|l|}{ Minimum FOS } \\
\hline & & $\begin{array}{l}\text { At } 95 \% \text { rainfall } \\
\text { intensity }\end{array}$ & $\begin{array}{l}\text { At maximum } \\
\text { rainfall intensity }\end{array}$ & & $\begin{array}{l}\text { At } 95 \% \text { rainfall } \\
\text { intensity }\end{array}$ & $\begin{array}{l}\text { At maximum } \\
\text { rainfall intensity }\end{array}$ \\
\hline 2015-2050 & 1.2638 & 1.2317 & 1.0013 & 1.2574 & 1.1975 & 0.9802 \\
\hline 2051-2075 & 1.2638 & 1.2172 & 0.9935 & 1.2574 & 1.1948 & 0.9661 \\
\hline 2076-2100 & 1.2638 & 1.2137 & 0.9989 & 1.2574 & 1.1921 & 0.977 \\
\hline
\end{tabular}


Fig. 11 Change in FOS with time at 95 percentile rainfall intensity
Fig. 12 Change in FOS with time at maximum rainfall intensity
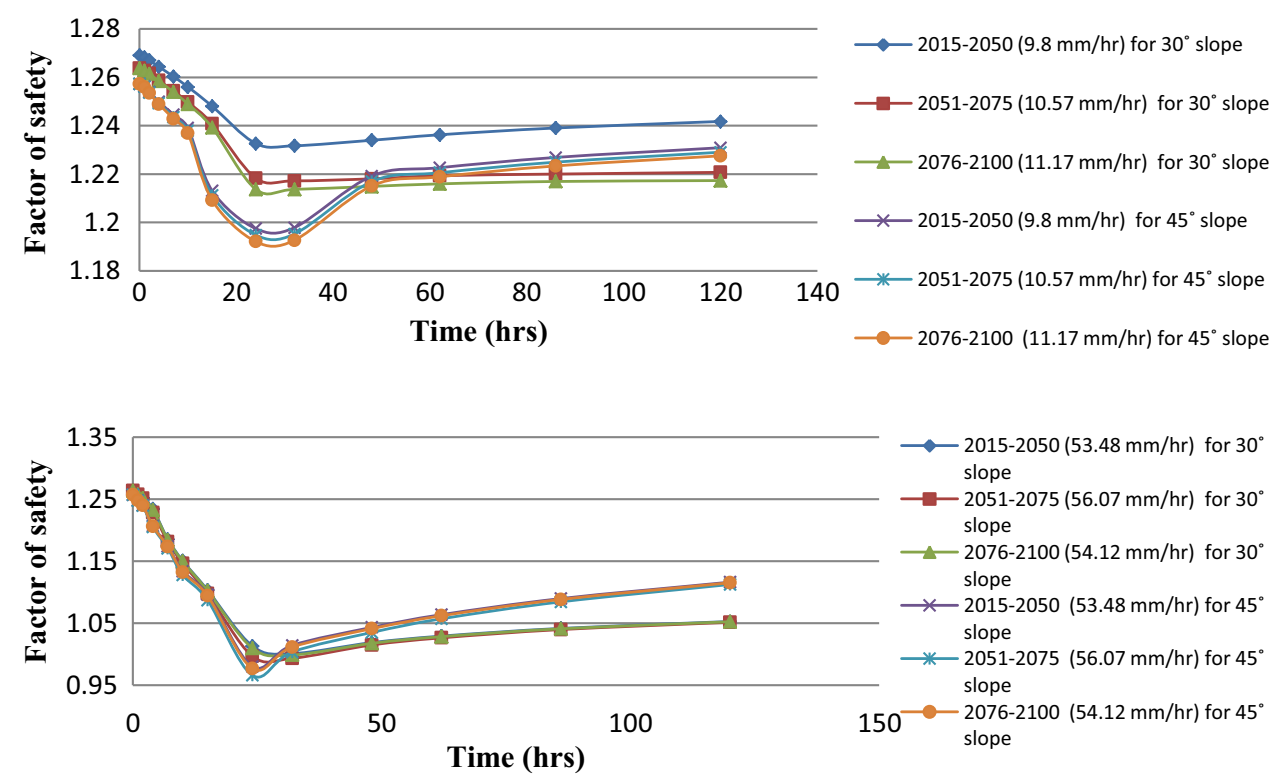

marginal for the period of 2051-2075 and 2076-2100 at $95 \%$, as well as at maximum rainfall intensity. Whereas in case of silt loam soil, the PWP at soil surface reaches near zero value $(8.7742 \mathrm{kPa})$ at the end of rainfall event (after $24 \mathrm{~h}$ of rainfall) at $95 \%$ rainfall intensity and after $2 \mathrm{~h}$ of commencement of rainfall at maximum rainfall intensity. The reason behind this early saturation of sandy loam soil is the rapid loss of matric suction, as well as of cohesion among soil particles. The relative changes in PWP for the period of 2051-2075 and 2076-2100 are also marginal for this soil.

\section{Change in Factor of Safety with Time}

The comparison in FOS for both the soil is given in Table 7. It is noted that for sandy loam soil, the percentage decrease in FOS from its initial value is $1.98 \%, 2.2 \%$ and $2.53 \%$ at $95 \%$ rainfall intensity and $20.59 \%, 20.15 \%$ and $21.49 \%$ at maximum rainfall intensity for the period of analysis 2015-2050, 2051-2075 and 2076-2100, respectively. The relative decrease in FOS for the period $2051-2075$ and $2076-2100$ is $0.22 \%$ and $0.56 \%$ at $95 \%$ rainfall intensity and $2.13 \%$ and $-4.4 \%$ at maximum rainfall intensity when compared to minimum FOS for the period 2015-2050. Whereas for silt loam soil, the percentage decrease in FOS from its initial value is $5.01 \%, 5.63 \%$ and $6.61 \%$ at $95 \%$ rainfall intensity and $33.62 \%, 33.44 \%$ and $33.79 \%$ at maximum rainfall intensity for the period of 2015-2050, 2051-2075 and 2076-2100, respectively. Also, the relative change in FOS for the period of 2051-2075 and $2076-2100$ is $0.65 \%$ and $1.68 \%$, respectively, at $95 \%$ rainfall intensity and $-0.28 \%$ and $0.24 \%$, respectively, at maximum rainfall intensity as compared to minimum FOS for the period 2015-2050. It is clear that there is a marginal change in FOS for sandy loam as well as for silt loam soil at maximum rainfall intensity of this area (Figs. 15, 16).

\section{Tamilnadu}

The results obtained by analyzing behavior of sandy silt soil slopes of Nilgiri hills with commencement of rainfall and are expressed as follows.

\section{Change in pore water pressure with time}

The pore water pressure profiles of sandy silt soil slope of Tamilnadu show that there is a continuous increase in pore water pressure from initial condition $(-15 \mathrm{kPa})$ up to the end of rainfall event due to reduction in matric suction which decreases further after cessation of rainfall event (Fig. 17). It is clearly observed that the increase in pore water pressure from its initial value (at $t=0 \mathrm{~h}$ ) to the end of rainfall event $(t=24 \mathrm{~h})$ is $-2.97 \mathrm{kPa},-2.34 \mathrm{kPa}$ and $-1.27 \mathrm{kPa}$ at the ground surface for the period of 2015-2050, 2051-2075 and 2076-2100, respectively, at 95 percentile rainfall intensity; whereas at maximum rainfall intensity, matric suction will disappear at ground surface after $1 \mathrm{~h}$ of rainfall for all the three period of analysis as the initial value of matric suction is very low and rainfall is highly intense.

\section{Change in FOS with Time}

The results show that the factor of safety of the sandy silt soil slope decreases from the initial state of slope with no rainfall up to the nearly saturated state (at 95 percentile 
(a)

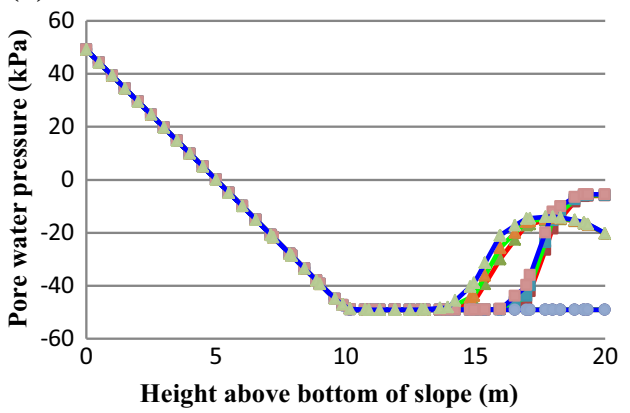

(b)

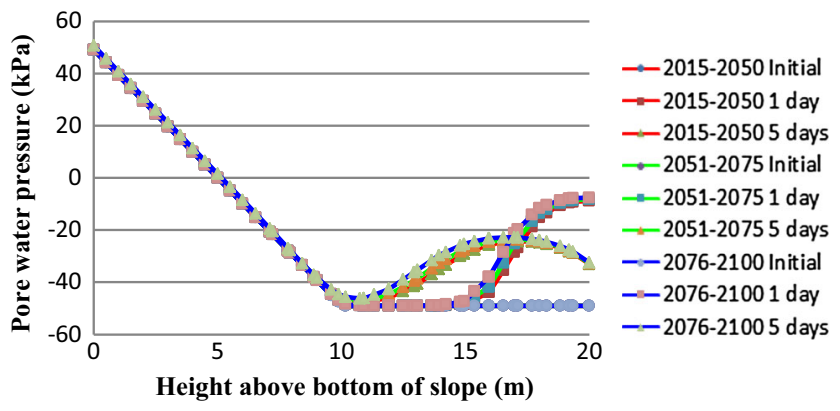

Fig. 13 Pore water pressure profiles at 95\% rainfall intensity a for sandy loam; and b for silt loam soil of hill slopes of Uttarakhand

(a)

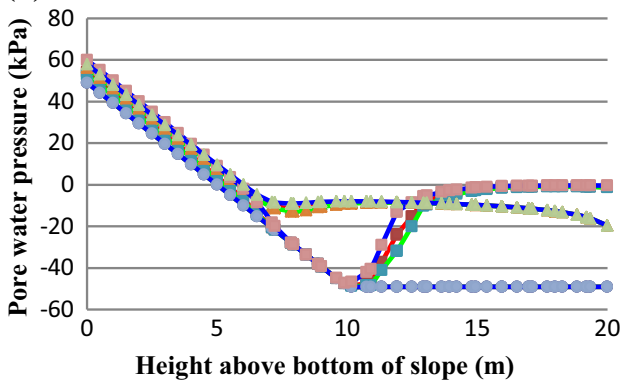

(b)

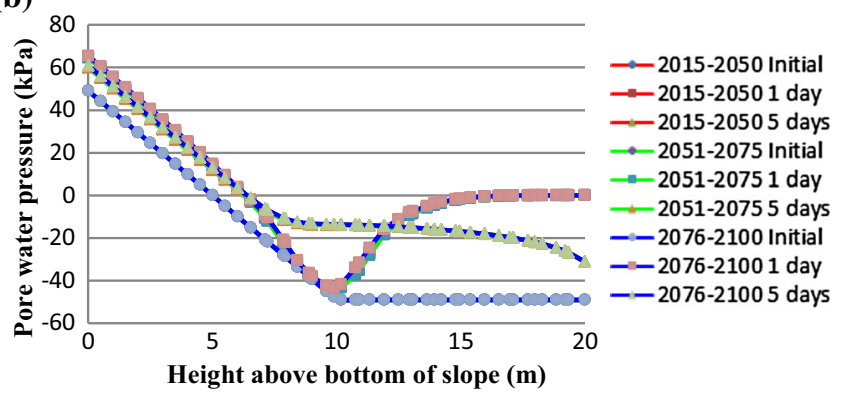

Fig. 14 Pore water pressure profiles at maximum rainfall intensity a for sandy loam; and $\mathbf{b}$ for silt loam soil of hill slopes of Uttarakhand

Table 7 Initial and minimum factor of safety for the soils of Uttarakhand

\begin{tabular}{|c|c|c|c|c|c|c|}
\hline \multirow{3}{*}{$\begin{array}{l}\text { Period of } \\
\text { analysis }\end{array}$} & \multicolumn{3}{|l|}{ Sandy loam soil } & \multicolumn{3}{|l|}{ Silt loam soil } \\
\hline & \multirow{2}{*}{$\begin{array}{l}\text { Initial FOS } \\
\text { At } 95 \% \text { and maximum } \\
\text { rainfall intensity }\end{array}$} & \multicolumn{2}{|l|}{ Minimum FOS } & \multirow{2}{*}{$\begin{array}{l}\text { Initial FOS } \\
\text { At } 95 \% \text { and maximum } \\
\text { rainfall intensity }\end{array}$} & \multicolumn{2}{|l|}{ Minimum FOS } \\
\hline & & $\begin{array}{l}\text { At } 95 \% \text { rainfall } \\
\text { intensity }\end{array}$ & $\begin{array}{l}\text { At maximum } \\
\text { rainfall intensity }\end{array}$ & & $\begin{array}{l}\text { At } 95 \% \text { rainfall } \\
\text { intensity }\end{array}$ & $\begin{array}{l}\text { At maximum } \\
\text { rainfall intensity }\end{array}$ \\
\hline $2015-2050$ & 1.35359 & 1.32685 & 1.0749 & 1.7677 & 1.58832 & 1.1099 \\
\hline 2051-2075 & 1.35359 & 1.32387 & 1.08084 & 1.7677 & 1.57803 & 1.11306 \\
\hline $2076-2100$ & 1.35359 & 1.31937 & 1.06265 & 1.7677 & 1.56169 & 1.1072 \\
\hline
\end{tabular}

Fig. 15 Change in FOS with time at 95 percentile rainfall intensity

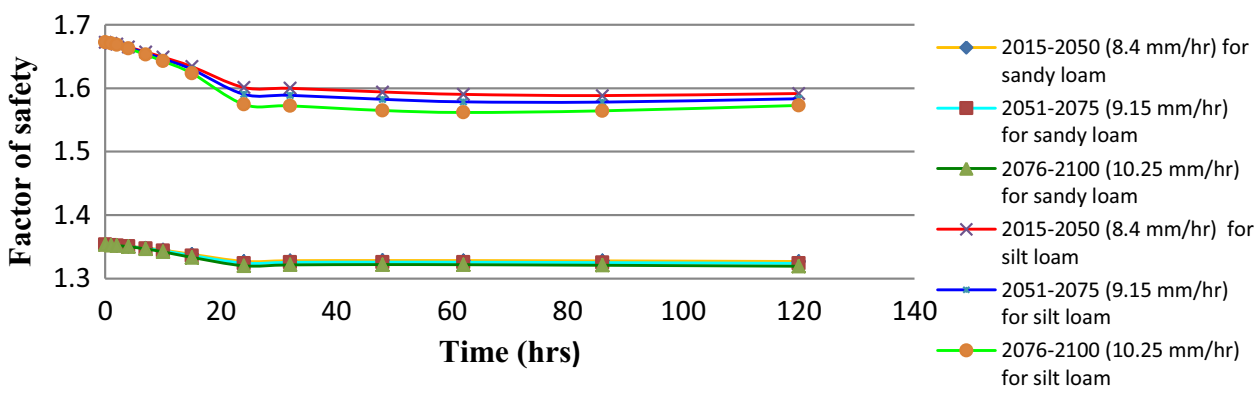

rainfall intensity) or fully saturated state (at maximum rainfall intensity) of soil (Fig. 18). The percentage decrease in FOS from its initial value to its minimum value (at $\mathrm{t}=24 \mathrm{~h})$ is $2.36 \%, 2.79 \%$ and $3.71 \%$ at $95 \%$ rainfall intensity; and 5.63\%, 5.63\% and $5.64 \%$ at maximum rainfall intensity for the period of 2015-2050, 2051-2075 and 2076-2100, respectively. Also, the relative change in FOS for the period of 2051-2075 and 2076-2100 is, 
Fig. 16 Change in FOS with time at maximum rainfall intensity

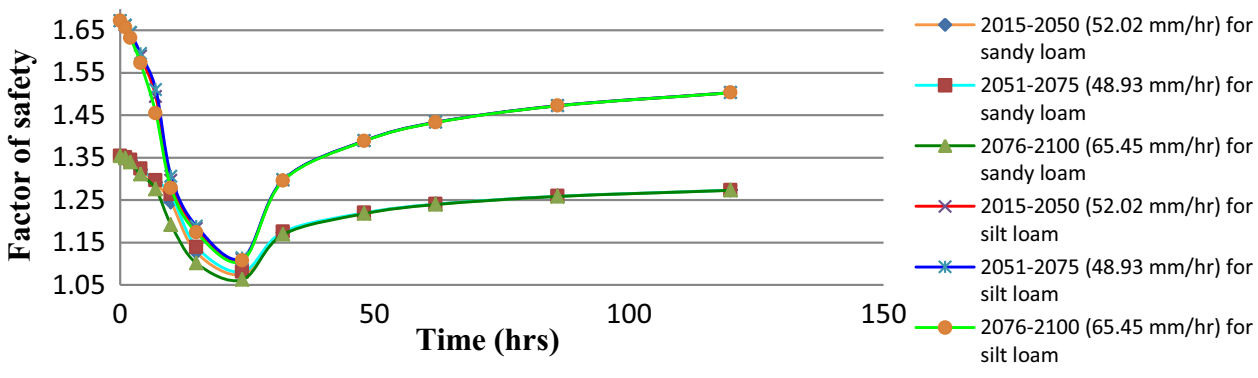

respectively, $0.44 \%$ and $1.39 \%$ at $95 \%$ rainfall intensity and $4.16 \times 10^{-5} \%$ and $6.4 \times 10^{-4} \%$ at maximum rainfall intensity as compared to minimum FOS for the period 2015-2050.

It is observed that the variation is negligible at maximum rainfall intensity for projected precipitation of 2051-2075 and 2076-2100 as compared to 2015-2050 because of the lower value of saturated hydraulic conductivity of soil (Table 8).

\section{Parametric Study}

\section{Effect of Slope Angle}

Analysis performed for Haflong (Assam) region of India shows dependency of pore water pressure profiles and corresponding factor of safety on slope angle as this analysis is performed for two slopes having same soil properties and slope height but having different slope angles, i.e., for $30^{\circ}$ and $45^{\circ}$ slope. A reduction in FOS with increasing slope angle is clearly observed with more reduction in matric suction at soil surface for $45^{\circ}$ slope as compared to $30^{\circ}$ slope.

This can be explained by the observed values of PWP at surface at the end of rainfall event for the period of 2015-2050 which are $-86.6437 \mathrm{kPa}$ and $-83.902 \mathrm{kPa}$ under 95 percentile rainfall intensity and $-13.3363 \mathrm{kPa}$ and $-3.6466 \mathrm{kPa}$ under maximum rainfall intensity for $30^{\circ}$ and $45^{\circ}$ slope angles. Its corresponding effect on FOS can be explained as for the same period of analysis (i.e., for 2015-2050) the value of FOS becomes 1.2317 and 1.1975 under 95 percentile rainfall intensity and 1.0013 and 0.9802 under maximum rainfall intensity for $30^{\circ}$ and $45^{\circ}$ slope angles.

\section{Effect of Soil Properties}

The analysis performed for Chamoli (Uttarakhand) region of India shows effect of soil properties on PWP profiles and FOS of soil slope. The analysis is performed for two different soils of this region which are sandy loam (SM) and silt loam (ML) soils considering the slope properties to be constant. From Table 2, it is clear that the values of strength parameters (i.e., $\gamma, \mathrm{c}$ and $\phi$ ) of sandy loam soil are less as compared to silt loam soil due to which the initial value of FOS for sandy loam soil is less than FOS for silt loam soil; also, the saturated hydraulic conductivity for sandy loam soil is higher than silt loam soil which accelerates the seepage of water into soil. Hence, under same conditions, more water will infiltrate into sandy loam soil slope as compared to silt loam soil slope resulting in more reduction in FOS. It is observed from the observations that the initial value of FOS for sandy loam soil is 1.35359 and for silt loam soil is 1.7677 .

The effect of soil properties is explained by the results obtained as the PWP at soil surface becomes zero after $7 \mathrm{~h}$ of continuous rainfall for sandy loam soil slope, whereas the value of PWP reaches to a near zero value even at the (a)

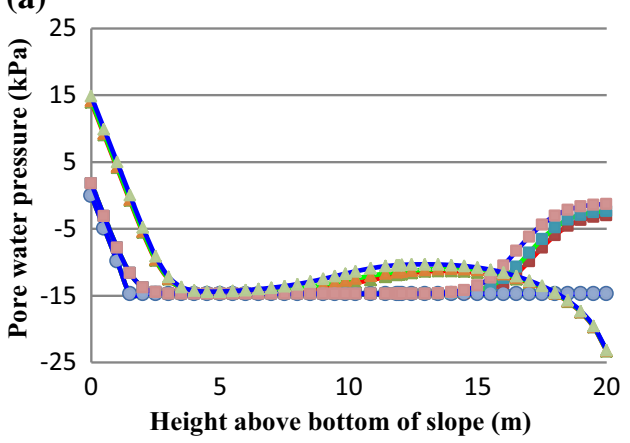

(b)

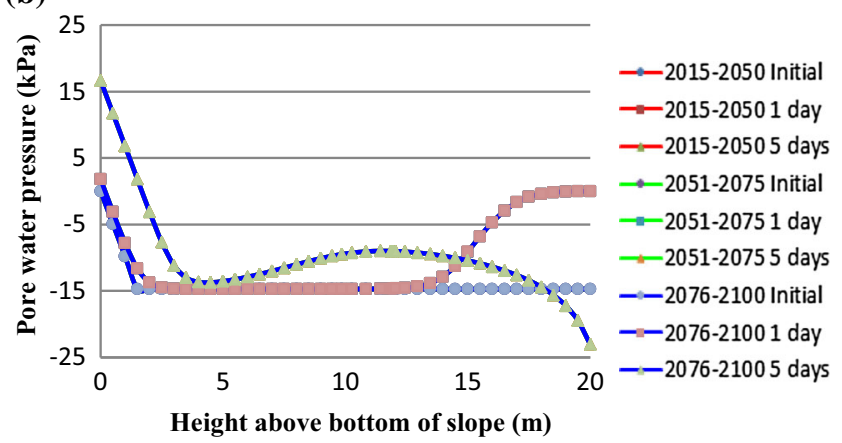

Fig. 17 Pore water pressure profiles for Nilgiri slope at a 95 percentile; and b maximum rainfall intensity 
Fig. 18 Change in FOS with time at 95 percentile and maximum rainfall intensity

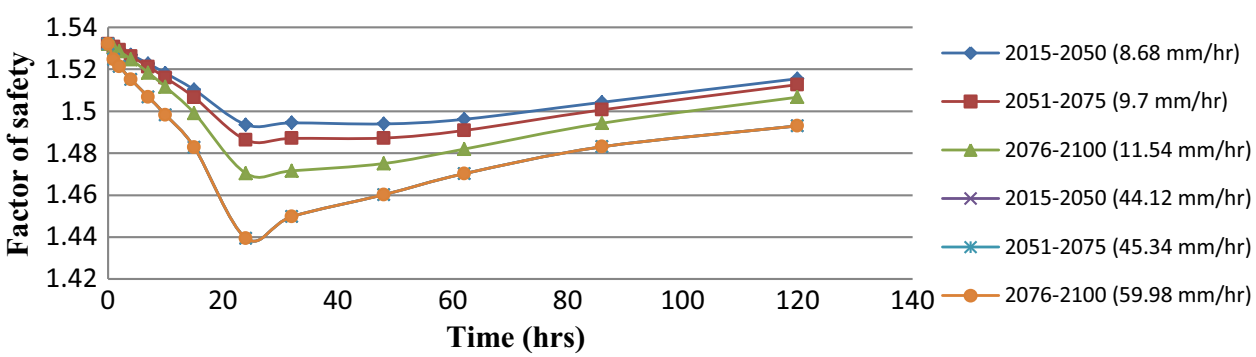

Table 8 Initial and minimum factor of safety values for Sandy silt soil of Tamilnadu

\begin{tabular}{|c|c|c|c|c|}
\hline \multirow[t]{2}{*}{ Period of analysis } & \multicolumn{2}{|c|}{ At 95 percentile rainfall intensity } & \multicolumn{2}{|c|}{ At maximum rainfall intensity } \\
\hline & Initial FOS & Minimum FOS & Initial FOS & Minimum FOS \\
\hline $2015-2050$ & 1.5290232 & 1.4929502 & 1.5290232 & 1.4428789 \\
\hline $2051-2075$ & 1.5290232 & 1.4864092 & 1.5290232 & 1.4428783 \\
\hline $2076-2100$ & 1.5290232 & 1.4722204 & 1.5290232 & 1.4428697 \\
\hline
\end{tabular}

end of rainfall event for silt loam soil slope under 95 percentile rainfall intensity; also, the PWP at soil surface becomes zero after $1 \mathrm{~h}$ of continuous rainfall for sandy loam soil slope, whereas this value becomes zero after $2 \mathrm{~h}$ of continuous rainfall for silt loam soil slope under maximum rainfall intensity. Considering the 2015-2050 period of analysis, the value of FOS becomes 1.32685 and 1.58532 under 95 percentile rainfall intensity for sandy loam soil and silt loam soil, respectively; also, the value of FOS becomes 1.0749 and 1.1099 under maximum rainfall intensity for sandy loam and silt loam soil, respectively.

\section{Effect of Rainfall Characteristics}

As per the rainfall data shown in Table 4, an increasing trend of rainfall intensity with passes of time is observed (considering 95 percentile rainfall data) and with this increasing rainfall, the slopes are becoming unstable due to reduction in factor of safety. This can be explained as the 95 percentile rainfall intensity for Nilgiri region is $8.68 \mathrm{~mm} / \mathrm{hr}, 9.7 \mathrm{~mm} / \mathrm{hr}$ and $11.54 \mathrm{~mm} / \mathrm{hr}$ under which the pore water pressure values at soil surface become $-2.97 \mathrm{kPa},-2.34 \mathrm{kPa}$ and $-1.27 \mathrm{kPa}$ and corresponding factor of safety becomes 1.429502, 1.4864092 and 1.4722204 for 2015-2050, 2051-2075 and 2076-2100 period of analysis, respectively. Hence, with these observations, the instability of slopes with increasing rainfall patterns can be easily understood and hence the slopes are to be analyzed under projected rainfall patterns rather than historical rainfall patterns that can lead to overestimation of FOS of soil slopes for future scenario.

\section{Summary}

A numerical simulation of rain-induced instability of slopes is performed for landslide prone regions of India to pre-detect the unsaturated soil slopes which are susceptible to failure due to rainfall infiltration. The study areas considered for simulation are Haflong (Assam), Chamoli (Uttarakhand) and Nilgiri (Tamilnadu). A coupled seepage and stability analysis is performed by SEEP/W and SLOPE/W programs of Geostudio 2018 R2 software, respectively, for slopes having distinct slope profiles and soil properties under 95 percentile and maximum rainfall intensity of three different periods 2015-2050, 2051-2075 and 2076-2100, so that the effect of climate change due to global warming can be checked using CMIP5 climate model with RCP8.5 carbon emission scenario. Results obtained from SEEP/W analysis in the form of PWP profiles are used as input in SLOPE/W analysis to check the stability of slope under transient seepage condition. A continuous reduction in pore water pressure is observed in all the cases with increasing rainfall intensity till the end of rainfall event, such as for Haflong soil slope of $45^{\circ}$ slope angle, the value of PWP at surface reduces from its initial value of $200 \mathrm{kPa}$ to $-83.9 \mathrm{kPa},-81.61 \mathrm{kPa}$ and $-79.89 \mathrm{kPa}$ at $11.62 \mathrm{~mm} /$ hr (for 2015-2050), $12.27 \mathrm{~mm} / \mathrm{h}$ (for 2051-2075) and $13.01 \mathrm{~mm} / \mathrm{h}$ (for 2076-2100) 95 percentile rainfall intensity, and reduction in matric suction can be clearly observed. With this reduction in matric suction, the value of FOS also decreases as the initial value of FOS for $45^{\circ}$ slope of Haflong is 1.2574, which reduces to 1.1975 , 1.1948 and 1.1921, respectively, with increasing 95\% rainfall intensity for above three periods of analysis due to 
changing climate. Also reduction in matric suction with increasing slope angle can be understood by the PWP value at slope surface at the end of rainfall event for $30^{\circ}$ and $45^{\circ}$ slope of Haflong at maximum rainfall intensity which are - $13.34 \mathrm{kPa}$ and $-3.65 \mathrm{kPa}$ respectively, and the corresponding values of FOS are 1.0013 and 0.9802 for analysis period 2015-2050. The effect of soil properties can be observed from sandy loam and silt loam soil of Uttarakhand which shows that the PWP at slope surface became zero after $7 \mathrm{~h}$ and $24 \mathrm{~h}$ at 95 percentile rainfall intensity and after $1 \mathrm{~h}$ and $2 \mathrm{~h}$ at maximum rainfall intensity, explaining that the water seeps more in sandy loam soil as compared to silt soil due to its high value of saturated hydraulic conductivity and hence the corresponding FOS values are lower for sandy loam than silt loam soil. The soil of Nilgiri is also having a lower value of saturated hydraulic conductivity, so the value of PWP reduced from $-15 \mathrm{kPa}$ to $-2.97 \mathrm{kPa},-2.34 \mathrm{kPa}$ and $-1.27 \mathrm{kPa}$ at slope surface with cessation of rainfall for 2015-2050, 2051-2075 and 2076-2100 period at 95 percentile rainfall causing a little change in FOS from 1.529 to $1.49,1.48$ and 1.46, respectively, due to lower value of initial negative pore water pressure.

\section{Conclusion}

Based on the obtained results, this study led to the following conclusions.

- With changing climate, rainfall is becoming more intense (from 95\% rainfall data), such as for Tamilnadu, 95 percentile rainfall intensity increases from 8.68 to $9.7 \mathrm{~mm} / \mathrm{h}$ for the period of 2015-2050 to 2051-2076, which further increases to $11.54 \mathrm{~mm} / \mathrm{h}$ for the period of 2076-2100, whereas the extreme rainfall patterns are uncertain which may increase or decrease accordingly (from maximum rainfall data), such as for the same region maximum rainfall intensity varies from $44.12 \mathrm{~mm} / \mathrm{h}$ to $45.34 \mathrm{~mm} / \mathrm{h}$ and further increases to $59.98 \mathrm{~mm} / \mathrm{h}$ for the periods 2015-2050, 2051-2075 and 2076-2100, respectively, showing a continuous increase but for Uttarakhand maximum rainfall intensity first decreases from 52.02 to $48.93 \mathrm{~mm} / \mathrm{h}$ for the period of 2015-2050 and 2051-2075, which now increases to $65.45 \mathrm{~mm} / \mathrm{h}$ for the period of 2076-2100.

- With increasing rainfall intensity, minimum value of FOS (generally obtained at the end of 1 day) is continuously decreasing due to reduction in matric suction, which can lead to slope failure in future, such as for Tamilnadu the initial value of FOS 1.529 decreases to $1.492,1.486$ and 1.472 for the period of 2015-2050, 2051-2075 and 2076-2100, respectively.
- As per a recent study by Deka et al. [13], factor of safety obtained at the end of 1 day of rainfall event is 1.212 and 1.007 for slope with slope angle $30^{\circ}$ and $45^{\circ}$, respectively. For the same rainfall conditions, the factor of safety in the present study is about 1.0013 and 0.9802 for slopes with slope angle $30^{\circ}$ and $45^{\circ}$, respectively.

- Parametric study performed for Haflong slope shows that with steepening of slope, factor of safety further reduces keeping all other factors constant, such as for Haflong region, the initial value of FOS is 1.2638 and 1.2574 for $30^{\circ}$ and $45^{\circ}$ slope, respectively. The results are consistent with many previous studies over India and around the Globe. Many studies have found an increase in the intensity of Landslides under changing climate scenario [31-33].

- Analysis for two different types of soil of Uttarakhand having same slope profile but different soil properties shows that a lower value of minimum FOS is obtained for sandy loam soil as compared to silt loam soil due to lower strength characteristics and higher value of saturated hydraulic conductivity (which allows more water to seep into soil) for sandy loam soil, such as under same rainfall intensity for the period of 2051-2075, the value of minimum FOS is 1.08 and 1.11 for sandy loam and silt loam soil, respectively.

- The sandy silt soil of Nilgiri hill slopes are marginally stable initially but these slopes are less affected by sudden rainfall, this might be because of the role of antecedent rainfall, which saturates the slope prior to the main rainfall event leading to failure of slope.

- These numerical simulations serve as early warning system in the region of severe landslides, which can cause massive destruction. So to reduce the risk of lives and property, there should be a proper stability analysis of the slope of a particular region.

- One of the major limitations of the study is that the input data used in this study for the SEEP/W and SLOPE/W program of Geostudio 2018 R2 software are taken from existing literature of those particular regions as laboratory experiments are not possible to be performed due to COVID-19 pandemic situation.

Funding No funding was received to assist with the preparation of this manuscript.

\section{Declaration}

Conflict of interest The author have no relevant financial or nonfinancial interests to disclose. 


\section{References}

1. Sarma, CP, Dey, A and Krishna, AM (2020). Investigation of rainfall-induced landslides at the Hillslopes of Guwahati Region, Assam. In: Katsumi T, Murali Krishna A (eds) Geotechnics for natural disaster mitigation and management. pp 75-87

2. Khanduri S, Sajwan KS, Rawat A, Dhyani C, Kapoor S (2018) Disaster in Rudraprayag District of Uttarakhand Himalaya: a special emphasis on geomorphic changes and slope instability. J Geogr Nat Disaster 8:100218

3. Pradhan SP, Vishal V, Singh TN (2018) Finite element modelling of landslide prone slopes around Rudraprayag and Agastyamuni in Uttarakhand Himalayan terrain. Nat Hazards 94:181-200

4. Gupta V, Bhasin RK, Kaynia AM, Tandon RS, Venkateshwarlu B (2016) Landslide Hazard in the Nainital township, Kumaun Himalaya, India: the case of September 2014 Balia Nala landslide. Nat Hazards 80:863-877

5. Ering P, Babu GLS (2016) Probabilistic back analysis of rainfall induced landslide: a case study of Malin landslide, India. Eng Geol 208:154-164

6. Dey N, Sengupta A (2018) Effect of rainfall on the triggering of the devastating slope failure at Malin, India. Nat Hazards. https://doi.org/10.1007/s11069-018-3483-9

7. Umrao RK, Singh R, Sharma LK, Singh TN (2017) Soil slope instability along a strategic road corridor in Meghalaya, northeastern India. Arab J Geosci 10:260

8. Dikshit A, Satyam N, Pradhan B (2019) Estimation of rainfallinduced landslides using the TRIGRS model. Earth Syst Environ. https://doi.org/10.1007/s41748-019-00125-w

9. Senthilkumar V, Chandrasekaran SS, Maji VB (2018) Rainfallinduced landslides: case study of the Marappalam Landslide, Nilgiris District, Tamil Nadu. India Int $J$ Geomech 18(9):05018006

10. Cascini L, Cuomo S, Pastor M, Sacco C (2013) Modelling the post-failure stage of rainfall-induced landslides of the flow type. Can Geotech J 50:924-934

11. Kristo C, Rahardjo H, Satyanaga A (2017) Effect of variations in rainfall intensity on slope stability in Singapore. Int Soil Water Conserv Res 5:258-264

12. Raj M, Sengupta A (2014) Rain-triggered slope failure of the railway embankment at Malda, India. Acta Geotech 9:789-798

13. Deka A, Daulagupu R, Brahma H, Lodger H, Dutta D (2020) Effect of antecedent rainfall on slope stability: a case study of Haflong Hill, North East India. J Geol Soc India 96:394-398

14. Jasim FH, Vahedifard F, Ragno E, AghaKouchak A, Ellithy G (2017) Effects of climate change on fragility curves of earthen levees subjected to extreme precipitations. Geo-Risk 285:498-507

15. Cho SE, Lee SR (2002) Evaluation of surficial stability for homogeneous slopes considering rainfall characteristics. J Geotech Geoenviron Eng 128:756-763

16. Collins BD, Znidarcic D (2004) Stability analyses of rainfall induced landslides. J Geotech Geoenviron Eng 130(4):362-372

17. Rahardjo H, Li XW, Toll DG, Leong EC (2001) The effect of antecedent rainfall on slope stability. Geotech Geol Eng 19:371-399
18. Brand EW, Premchitt J, Phillipson HB (1984). Relationship between rainfall and landslides in Hong Kong. In: Proceeding of the 4th international symosium on landslides, Toronto, vol 1 , pp 377-384

19. Rahardjo H, Ong TH, Rezaur RB, Leong EC (2007) Factors controlling instability of homogeneous soil slopes under rainfall. J Geotech Geoenviron Eng 133:1532-1543

20. Robinson JD, Vahedifard F, AghaKouchak A (2017) Rainfall triggered slope instabilities under a changing climate: comparative study using historical and projected precipitation extremes. Can Geotech J 54:117-127

21. Chandrasekaran SS, Owaise RS, Ashwin S, Jain RM, Prasanth S, Venugopalan RB (2013) Investigation on infrastructural damages by rainfall-induced landslides during November 2009 in Nilgiris, India. Nat Hazards 65:1535-1557

22. Mathew J, Babu DG, Kundu S, Kumar KV, Pant CC (2014) Integrating intensity-duration-based rainfall threshold and antecedent rainfall-based probability estimate towards generating early warning for rainfall-induced landslides in parts of the Garhwal Himalaya, India. Landslides 11:575-588

23. Ansari T, Kainthola A, Singh KH, Singh TN, Sazid M (2021) Geotechnical and micro-structural characteristics of phyllite derived soil; implications for slope stability, Lesser Himalaya, Uttarakhand, India. Catena, Vol. 196, p. 104906.

24. Mathew J, Kundu S, Kumar KV, Pant CC (2016) Hydrologically complemented deterministic slope stability analysis in part of Indian Lesser Himalaya. Geomat Nat Haz Risk 7:1557-1576

25. Vadivel S, Sennimalai CS (2019) Failure mechanism of longrunout landslide triggered by heavy rainfall in Achanakkal, Nilgiris, India. J Geotech Geoenviron Eng 145(9):04019047

26. Geoslope International Ltd. (2012) Geostudio . SEEP/W for finite element seepage analysis. Calgary, Alberta, Canada.

27. Van Genuchten MT (1980) A closed-form equation for predicting the hydraulic conductivity of unsaturated soil. Soil Sci Soc Am J 44(5):892-898

28. Fredlund DG, Xing A (1994) Equations for the soil-water characteristic curve. Can Geotech J 31:533-546

29. Geoslope International Ltd. (2012) Geostudio. SLOPE/W for slope stability analysis. Calgary, Alberta, Canada.

30. Morgenstern NR, Price VE (1965) The analysis of the stability of general slip surfaces. Geotechnique 15(1):79-93. https://doi.org/10.1680/geot.1965.15.1.79

31. Jakob M, Lambert S (2009) Climate change effects on landslides along the southwest coast of British Columbia. Geomorphology 107(3-4):275-284

32. Kumari S, Chauhan A, Shankar V (2021) Assessment of climate change implications on landslides in mid and high hills of Himachal Pradesh. India Arab J Geosci 14(14):1-15

33. Patton AI, Rathburn SL, Capps DM (2019) Landslide response to climate change in permafrost regions. Geomorphology 340:116-128

Publisher's Note Springer Nature remains neutral with regard to jurisdictional claims in published maps and institutional affiliations. 